\title{
Ultrastructural and Immunohistochemical Effects of Aqueous Leave Extract of Xylopia aethiopica on the Stomach in Streptozotocin-Induced Diabetic Rats
}

\author{
Efectos Ultraestructurales e Inmunohistoquímicos del Extracto Acuoso de la Hoja Xylopia \\ aethiopica en el Estómago de Ratas Diabéticas Inducidas por Estreptozotocina
}

\author{
D. A. Ofusori" ${ }^{*, * *}$; O. A Komolafe*; O. S. Adewole*; B. E. Arayombo*; D. Margolis ${ }^{* * *}$ \& T. Naicker ${ }^{* *}$
}

OFUSORI, D. A.; KOMOLAFE, O. A; ADEWOLE, O. S.; ARAYOMBO, B. E; MARGOLIS, D. \& NAICKER, T. Ultrastructural and immunohistochemical effects of aqueous leave extract of Xylopia aethiopica on the stomach in streptozotocin-induced diabetic rats. Int. J. Morphol., 34(1):34-41, 2016.

SUMMARY: Gastrointestinal pathology in diabetic patients has become a source of concern in recent times. The aim of this study was to investigate the ultrastructural and immunohistochemical effects of aqueous leaf extract of Xylopia aethiopica on the stomach in streptozotocin-induced diabetic rats. This study was conducted using thirty adult Wistar rats. The animals were divided into three groups ( $\mathrm{n}=$ 10). Group A was the control animals (administered with equivalent volume of citrate buffer), group B was diabetic animals induced by a single intraperitoneal injection of streptozotocin dissolved in citrate buffer $(65 \mathrm{mg} / \mathrm{kg})$ and group C was diabetic animals treated with $200 \mathrm{mg} /$ $\mathrm{kg}$ body weight of aqueous leave extract of X. aethiopica for twenty five days. At the expiration of the study, all the animals in each of the groups were sacrificed and the stomach excised and fixed in both $10 \%$ formol and karnovsky fixatives immunohistochemical, light microscopic and electron microscopic studies respectively. The results showed a gradual decline $(\mathrm{P}<0.05)$ in the blood glucose level in the extract treated group as against the increment in untreated diabetic group. There was a distortion of the glandular mucosa and epithelium in the untreated diabetic group vis-à-vis the extract treated and control groups. The immunohistochemical staining and percentage immunoreactivity of the stomach of untreated diabetic group showed that the immunoexpression of $\mathrm{H}+\mathrm{K}+$-ATPase were sparse and significantly $(\mathrm{p}<0.000)$ lower compared with the control group. There was a better staining pattern for $\mathrm{H}+/ \mathrm{K}+$-ATPase gastric proton pump in the group treated with aqueous leaf extract of $X$. aethiopica as compared with the untreated diabetic group. The ultrastructural studies of untreated diabetic group revealed a reduction in the density of mitochondria as compared with the control group. Treatment with leaf extract of $X$. aethiopica increased the mitochondrial density as well as uniform dispersal of chromatin. It is concluded that diabetes causes gastric pathology thus resulting in morphological changes in the gastric histo-architecture and parietal cells. The aqueous leaf extract of X. aethiopica enhances the recovery/ restoration of these defects in streptozotocin induced diabetic rats and as such, may play a significant role in the management of complications associated with diabetes mellitus.

KEY WORDS: Diabetes mellitus; Immunohistochemistry; Ultrastructure; Stomach; Xylopia aethiopic.

\section{INTRODUCTION}

Diabetes mellitus (DM) is a metabolic disorder of the endocrine system (Deshmukh et al., 2008). It is a group of metabolic diseases characterized by high blood glucose levels, which result from defects in insulin secretion, or action, or both. Diabetes mellitus is sometimes referred to as diabetes was first identified as a disease associated with "sweet urine". Basically we have two types of diabetes, called type 1 and type 2. Type 1 diabetes is also called insulin dependent diabetes mellitus (IDDM), or juvenile onset diabetes mellitus. In type 1 diabetes, the pancreas undergoes an autoimmune attack, and thus unable to make insulin. Type 2 diabetes is also known as non-insulin dependent diabetes mellitus (NIDDM), or adult onset diabetes mellitus (AODM). In type 2 diabetes, patient continues to produce insulin, but the insulin is not enough to meet up with the body's needs. The release of insulin by the pancreas is affected by a steady decline in beta (b) cell production of insulin in type 2 diabetes that contributes to worsening glucose control. Because of inability to produce insulin by people suffering from diabetes, they have a high level of blood glucose (Deshmukh $\mathrm{et}$

\footnotetext{
* Department of Anatomy and Cell Biology, Faculty of Basic Medical Sciences, Obafemi Awolowo University, Ile-Ife, Nigeria.

** Optics and Imaging Centre, School of Laboratory Medicine \& Medical Sciences, University of KwaZulu-Natal, Durban, South Africa.
} 
$a l$.). Streptozotocin induction of diabetes is an experimental model widely used to study glycemic and lipidemic changes in plasma (Bailey \& Day, 1989). Although the precise mechanism is not known, streptozotocin decreases insulin secretion from the b-cell of the pancreas (Deshmukh et al.).

The stomach is a very important visceral whose mechanical activity helps to churn ingested food into smaller fragments. The stomach is one of the numerous visceral compromised in patients with DM. Both acute and chronic hyperglycemia can lead to specific gastrointestinal (GI) complications. DM is a systemic disease that may affect many organ systems, and the GI tract is no exception. As with other complications of diabetes, the duration of the disorder and poor glycemic control seem to be associated with more severe GI problems. Patients with a history of retinopathy, nephropathy, or neuropathy should be presumed to have GI abnormalities until proven otherwise, and this is best determined by asking a few simple questions (Wolosin \& Edelman, 2000). Diabetic gastroparesis is a condition in which emptying of food from the stomach is delayed, leading to retention of stomach contents. This may cause bloating, early satiety, distention, abdominal pain, nausea, or vomiting. Gastric stasis may lead to worsening gastroesophageal reflux along with symptoms of heartburn and mechanical regurgitation of gastric contents. In addition, fatty foods and very fibrous foods normally exit the stomach slowly and may be poorly tolerated (Piyachaturawat et al., 1991).

Relationships between diabetes and stomach have been of almost importance considering the vital role of the stomach in the body. Gastroparesis is one of diabetic gastrointestinal motor disturbances, and occur in approximately $50 \%$ of diabetic patients (Yamano et al., 1997). The pathogenesis of diabetic gastroparesis however remains poorly understood. Acute changes in blood glucose level affect gastric emptying in healthy men (Yamano et al.). Ofusori et al. (2012) reported diabetic gastroparesis in adult Wistar rats. Also, Bastaki et al. (2010) concluded that longterm diabetes induces cellular and functional changes in the glandular stomach especially in the parietal cells.

For various reasons, in recent years the popularity of complementary medicine has increased. Dietary measures and traditional plant therapies are used commonly in Nigeria. Herbs such as Xylopia aethiopica (X. aethiopica) are known to act as anti-diabetic agents (Ogbonnia et al., 2008; Baldé et al., 2006), but the effects of such herbs on complications such as gastric complication associated with diabetes is yet to be thoroughly investigated.

The aim of this study was to determine the effect and role of $X$. aethiopica leaf extract (if any) on the restoration of gastric integrity compromised during diabetic state and to also justify its ethno-medicinal use in the management of DM.

\section{MATERIAL AND METHOD}

Animal care. Thirty adult male albino rats of the Wistar strain were procured and acclimatized for two weeks before the commencement of the research work. Animals were fed with standard rat feed. Animals were kept and maintained under standard laboratory conditions of light, humidity and temperature. All the animal experiments were conducted in accordance with the "Guide for the Care and Use of Laboratory Animals" prepared by the institute of public health, Obafemi Awolowo University (Ethics No: IPHOAU/12/61).

Plant Materials. The plant (X. aethiopica) was procured from a local market in Ile-Ife, Osun State, Nigeria. The leaf was identified by a taxonomist at the Department of Botany, Obafemi Awolowo University, Nigeria. The leaves were weighed (310 g), air dried and crushed in to powder by a squeezing and crushing machine (Daiki Rika Kogyo CoLtd, Japan). The powder was then weighed and extracted with distilled water $(2.5 \mathrm{~L})$. The solution was given an average of two intermittent shaking per hour. After fourty-eight hours, the solution was filtered and the filtrate concentrated in vacuum using rotary evaporator (Buchi Rotavapor R110, Schweiz). The yield (5.93\%) was weighed and administered at a dose of $200 \mathrm{mg} / \mathrm{kg}$ to the animals in group C.

Induction of experimental diabetes. The animals in groups $\mathrm{B}$ and $\mathrm{C}$ were injected intraperitoneally with streptozotocin (STZ) $(65 \mathrm{mg} / \mathrm{kg}$ body weight) dissolved in $0.1 \mathrm{M}$ sodium citrate buffer ( $\mathrm{pH}$ 6.3) while animals in group A received an equivalent volume of $0.1 \mathrm{M}$ sodium citrate buffer ( $\mathrm{pH}$ 6.3). Streptozotocin induces diabetes within $3 \mathrm{~d}$ by destroying the beta cells (Akbarzadeh et al., 2007). Before the commencement of the experiments, all the animals were fasted for 16-h, but still allowed free access to water throughout. At the end of the 16-h fasting period - taken as 0-h - blood glucose levels (initial glycemia, G0) of the fasted normal (control), and other experimental rats were determined and recorded using Accu-check ${ }^{\circledR}$ Advantage, Roche Diagnostic, Germany. Blood glucose levels was again determined and recorded on the $3^{\text {rd }}, 14^{\text {th }}$ and $28^{\text {th }} \mathrm{d}$. As soon as hyperglycemia was confirmed $3 \mathrm{~d}$ after STZ induction, animals in group $\mathrm{C}$ were immediately treated with the leaf extract of $X$. aethiopica in aqueous solution orally through gavages at a concentration of $200 \mathrm{mg} / \mathrm{kg}$ body weight/rat/ day until the $28^{\text {th }} \mathrm{d}$. 


\section{Experimental design.}

The animals were divided into three groups as follows, with ten animals in each group:

Group A: Control rats administered intraperitoneally with equivalent volume of $0.1 \mathrm{M}$ sodium citrate buffer.

Group B: Diabetic control rats administered intraperitoneally with $65 \mathrm{mg} / \mathrm{kg}$ body weight dissolved in $0.1 \mathrm{M}$ sodium citrate buffer ( $\mathrm{pH}$ 6.3).

Group C: Diabetic rats administered orally aqueous leaf extract of Xylopia aethiopica $(200 \mathrm{mg} / \mathrm{kg}$ body weight/day/ rat) in aqueous solution for twenty five days which commenced three days after STZ induction.

Light Microscopy. Samples of the stomach of the sacrificed animals were fixed in $10 \%$ formol saline and processed for light microscopic study. These processing methods include dehydration through graded ethanol $(50 \%, 70 \%, 90 \%$ and $100 \%$ ), clearing in isopropanol and infiltration in paraffin wax for $2 \mathrm{~h}$ at $56^{\circ} \mathrm{C}$ using automatic tissue processor (Leica ASP 200S). The processed samples were then embedded in paraffin wax for 48 hours using auto-embedder (Leica EG1150 H). Sections were obtained using a rotary microtome (Leica RM 2135) at $5 \mu \mathrm{m}$ thickness. The sections were finally subjected to Haematoxylin and Eosin (H \& E) staining procedure.

Immunohistochemistry. For each stomach, 10 sections were randomly chosen at every $30^{\text {th }}$ section throughout the block (Bernard et al., 1998; Movassat et al., 1997). Sections of the stomach were immunostained with monoclonal antibodies against $\mathrm{H}+/ \mathrm{K}+$-ATPase (1:2000 dilution), gastric proton pump, for $24 \mathrm{~h}$ at $4{ }^{\circ} \mathrm{C}$. Thereafter, incubated in peroxidase-conjugated rabbit anti-guinea pig immunoglobulin $\mathrm{G}(\mathrm{IgG})$ (final dilution 1:20) for $30 \mathrm{~min}$.
The activity of the antibody-peroxidase complex was visualized by incubation with 3,3'-diaminobenzidine-tetrahydrochloride (DAB kit). Sections were counterstained with hematoxylin and mounted in DPX. The sections were examined under a bright field on a Zeiss Axioscope A1 microscope with a digital camera attached.

Percentage Immunoreactivity. Eight areas of the stomach per specimen were randomly selected and photographed at magnification $\times 100$. The intensity of labeling with $\mathrm{H}+/ \mathrm{K}+-$ ATPase antibody was evaluated with Zeiss AxioVision Image analysis software package version 4.8.3. The size of the measurement frame was expressed as $\mu \mathrm{m}^{2}$. This measurement corresponded to a mean area frame of $359142.31 \mu \mathrm{m}^{2}$. Intensity of immunoreactivity was expressed as percent labeled surface area / frame surface area.

Electron Microscopy. The gastric tissue from each group of sacrificed animals was fixed Karnovsky fixative (American MasterTech Scientific, Inc.). The tissues were subsequently post-fixed in $1 \%$ osmium tetroxide. After dehydration in graded concentrations of ethyl alcohol and propylene oxide using an automatic tissue processor (Leica EM TP), the tissues were embedded in spur medium. Samples were sectioned with an ultramicrotome Reichert Ultracut $\mathrm{S}$, using a glass knife. Semi-thin sections were stained with methylene blue, and ultra-thin sections with 8 $\%$ uranyl acetate dissolved in $50 \%$ methanol, and thereafter in lead citrate according to the method of Reynolds (1963). All the sections on a grid were viewed under a Transmission Electron Microscope (JEM-1011).

Statistical Analysis. All data were expressed as Mean \pm Standard Error of Mean (S.E.M) and evaluated by one-way analysis of variance (ANOVA) using SPSS version 17.0 (SPSS, Cary, NC, USA) with Duncan's Multiple Range Test (DMRT) option.

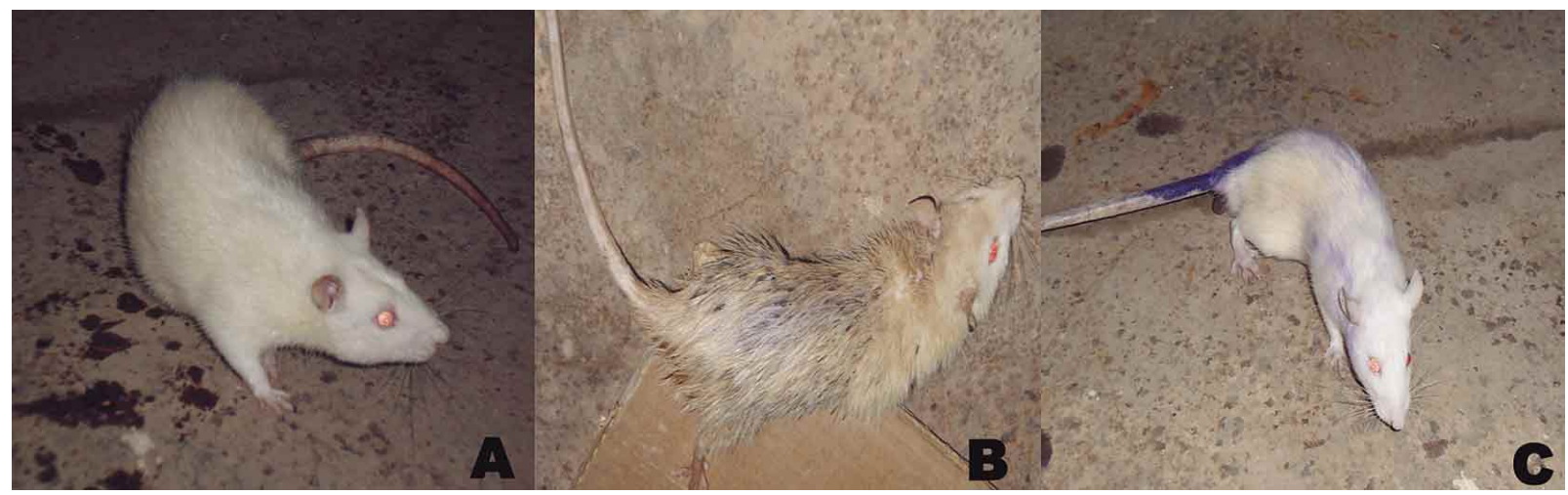

Fig. 1. Showing a representative of animals from each group. (A) Group A (Control group); (B) Group B (Untreated diabetic group), note the wetness of the fur; (C) Group C (Diabetic group treated with X. aethiopica). 


\section{a BLOOD GLUCOSE LEVEL}

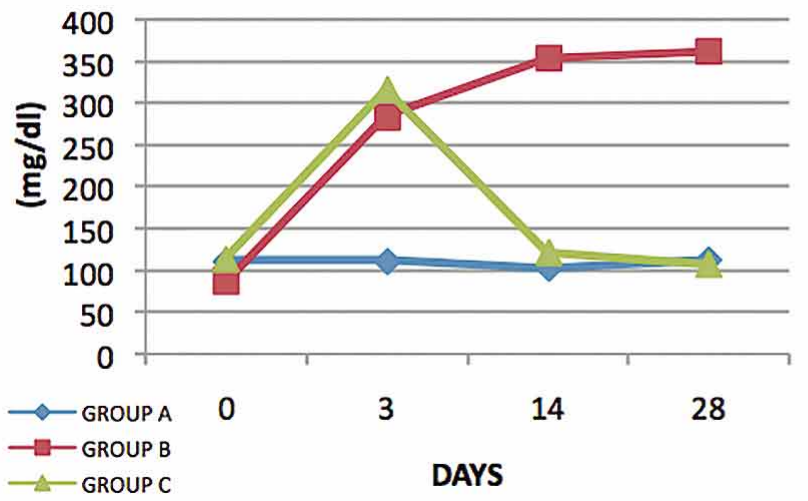

\section{C \% RELATIVE STOMACH WEIGHT}

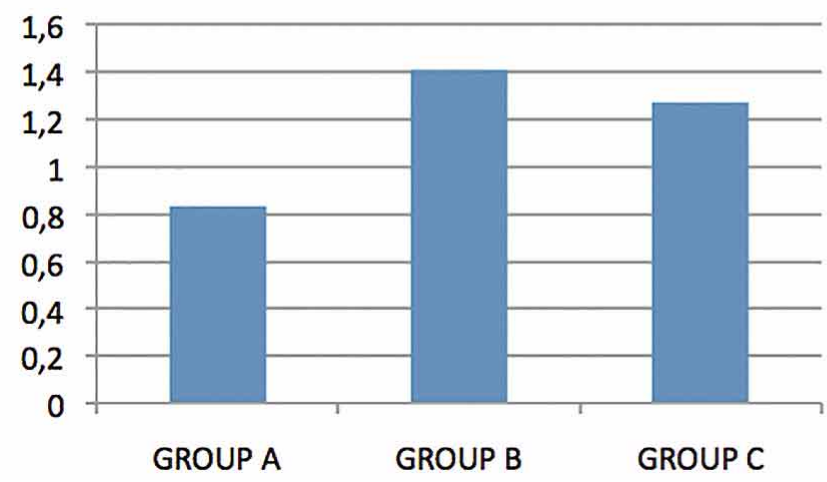

\section{RESULTS}

Physical Examination. The physical examination of the animals in all groups showed that untreated diabetic animals were characterized by alopecia. The furs were also seen to be wet when compared with animals from the control and extract treated groups (Fig.1).

\section{b BODY WEIGHT}

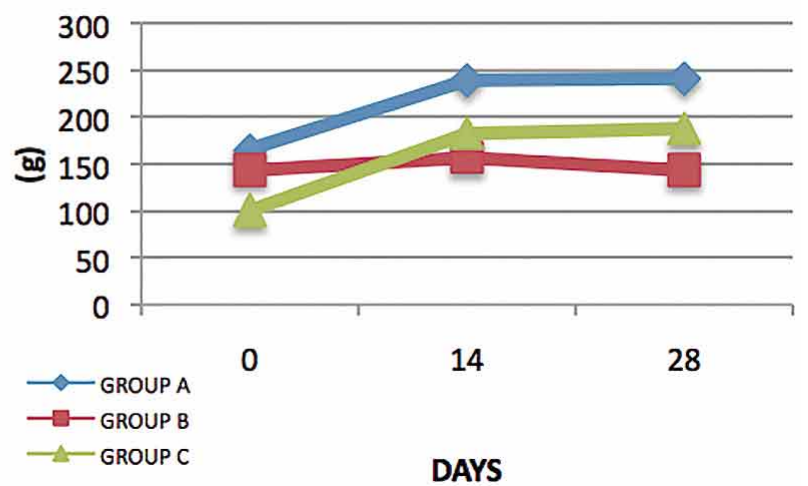

Fig. 2. a) Chart showing the average blood glucose level (mg/dL). b) Chart Showing the average body weight $(\mathrm{g})$. c) Histogram showing the relative stomach weight $(\%)$.

Blood Glucose Level. The result from this study showed that there was a significant $(\mathrm{P}<0.05)$ reduction in the average blood glucose level in the extract treated group vis-à-vis the untreated diabetic group (Fig. 2a).

Body weight and \% Relative Stomach Weight. Animals in the untreated diabetic group showed a gradual decline in the body weight as compared with the control. The extract treated group however showed an improvement in their average body weight as shown in Figure $2 \mathrm{~b}$. The percentage relative stomach weight was increased in the untreated diabetic group as compared with the control and extract treated group (Fig. 2c).

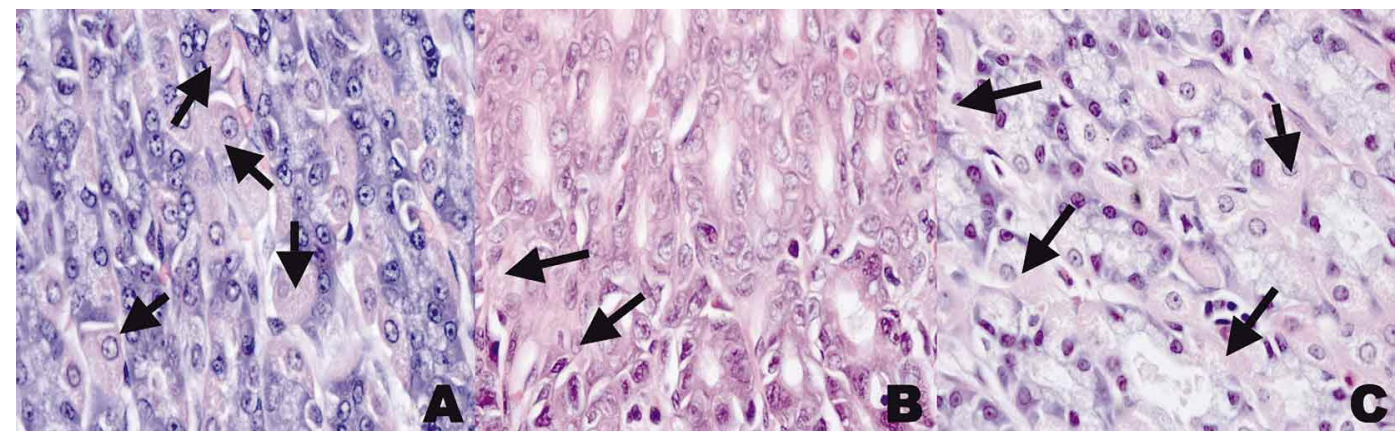

Fig. 3. Photomicrograph of the Stomach of (A) Group A, note the numerous parietal cells (arrow); (B) Group B, note the scanty parietal cells (arrow); (C) Group C, note the gradual restoration of parietal cells (arrow) as compared with Group A (H\&E, x400) 
Histological Evaluation. There was a distortion of the glandular mucosa, epithelium and depletion of the parietal cells in the untreated diabetic group. The extract treated and control groups however presented a well preserved microstructural outline. There were gradual restorations of the parietal cells in the extract treated group (Fig. 3).

Immunohistochemical Evaluation. The immunohistochemical staining of the stomach of untreated diabetic group showed that the immunoreactivity for $\mathrm{H}+/ \mathrm{K}+$-ATPase positive parietal cells were sparse vis-à-vis control group. There was a better immunoreactivity for $\mathrm{H}+/ \mathrm{K}+$-ATPase positive parietal cells in the group treated with aqueous leaf extract of $X$. aethiopica as compared with the untreated diabetic group (Fig. 4). The percentage immunoreactivity was significantly higher $(\mathrm{p}<0.000)$ in group $C$ compared with group B as shown in Table 1. There was a non significant difference when group $\mathrm{C}$ was compared with the control group (group A).

Ultrastructural evaluation. The ultrastructural study of untreated diabetic group revealed a reduction in the density of mitochondria in addition to predominance of euchromatin over heterochromatin in the nucleus of parietal cells as compared with the control group. Administration of extracts of $X$. aethiopica to animals in group $\mathrm{C}$ gradually restores the mitochondrial density as well as the chromatin in the nucleus to near normal as shown in Fig. 5

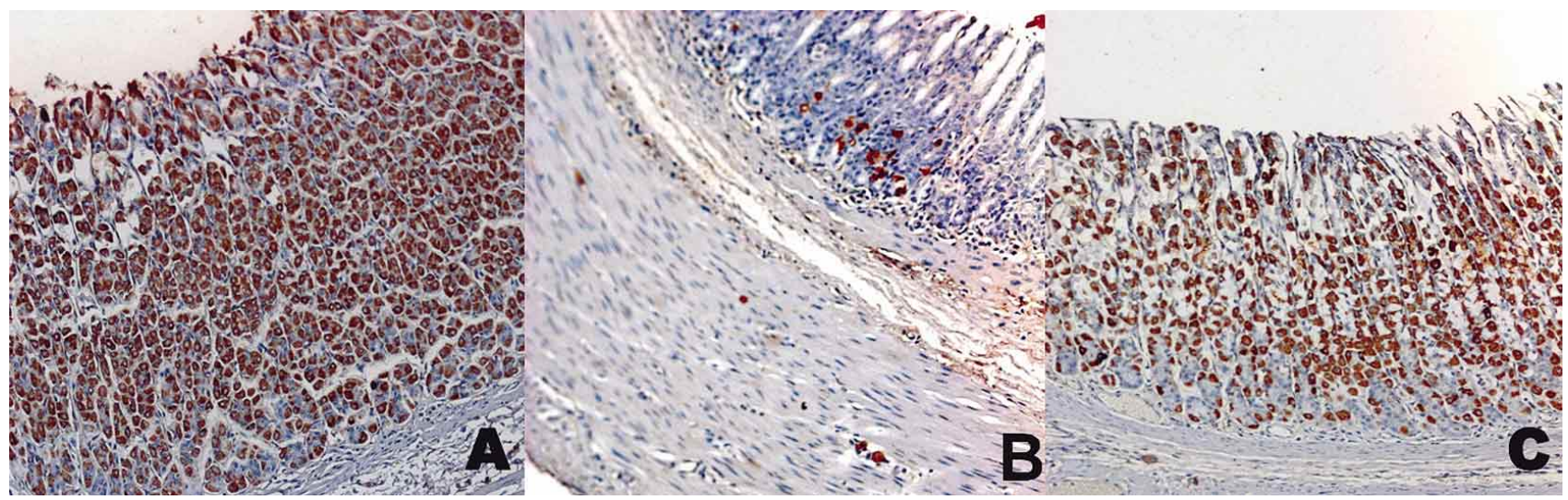

Fig. 4. Photomicrograph of the Stomach of (A) Group A, note the numerous H+/K+-ATPase positive parietal cells (Brown color); (B) Group B, note the scanty $\mathrm{H}+/ \mathrm{K}+$-ATPase positive parietal cells (Brown color); (C) Group C, note the gradual restoration of $\mathrm{H}+\mathrm{K}+-\mathrm{ATPase}$ positive parietal cells (Brown color) as compared with Group A (Magnification= x100).

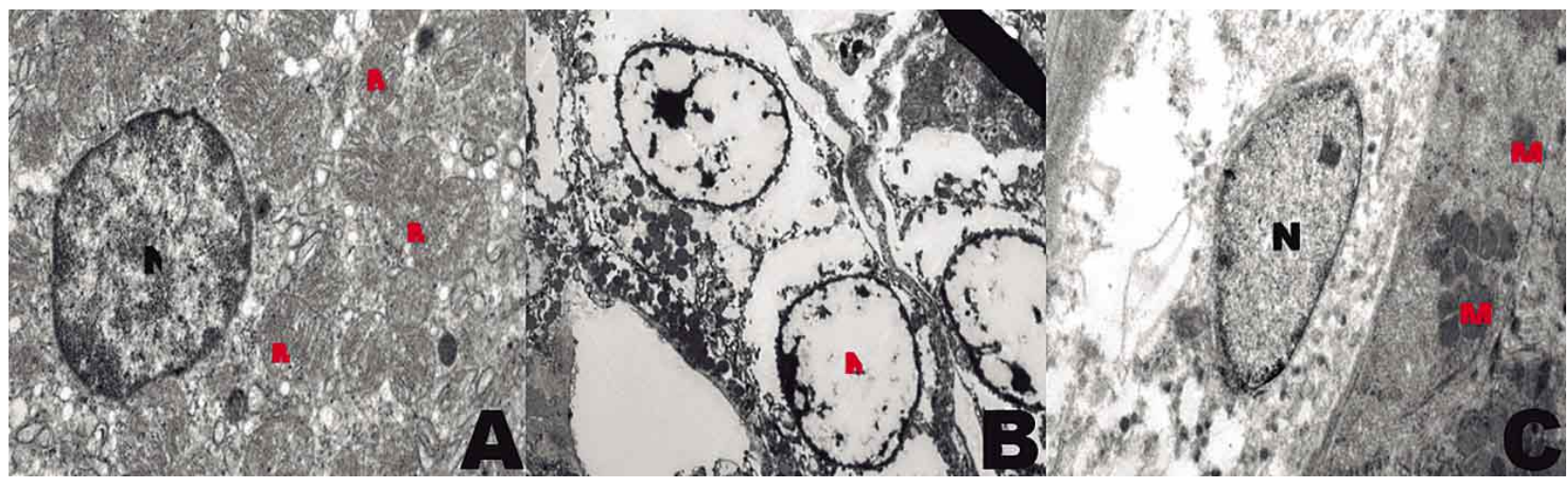

Fig. 5. Electromicrograph of the Stomach (Parietal cell) of (A) Group A, note the numerous mitochondria (M). (B) Group B, note the decline in the density of mitochondria as well as abundant euchromatin in the nucleus (N). (C) Group C, note the similar dispersal of chromatin nature within the nucleus as well as the gradual restoration of the mitochondrial (M) compared with Group A (EM x15, 000).

Table I. Morphometric image analysis of $\mathrm{H}+/ \mathrm{K}+$-ATPase immunoreactivity in Xylopia aethiopica and STZ-induced diabetic rats.

\begin{tabular}{lcccc}
\hline & GROUP A & GROUP B & GROUP C & P VALUE \\
\hline Area field $\boldsymbol{\mu m}^{2}$ & 359142.31 & 359142.31 & 359142.31 & \\
Immunoreactivity \% & $22.91 \pm 2.12 \mathrm{~b}$ & $2.02 \pm 0.58^{\mathrm{a}}$ & $19.80 \pm 4.04 \mathrm{~b}$ & 0.000 \\
\hline
\end{tabular}

Values are given as Mean \pm SEM. $a \& b$ within row signifies that Means with different letters differs significantly while Means with the same letters does not differ significantly (using one way ANOVA with Duncan multiple range test). 
OFUSORI, D. A.; KOMOLAFE, O. A; ADEWOLE, O. S.; ARAYOMBO, B. E; MARGOLIS, D. \& NAICKER, T. Ultrastructural and immunohistochemical effects of aqueous leave extract of Xylopia aethiopica on the stomach in streptozotocin-induced diabetic rats. Int. J. Morphol., 34(1):34-41, 2016.

\section{DISCUSSION}

There have been a less concentrations on the cellular details of the complications arising from diabetes mellitus. The stomach has however received in fact less attention based on literature search. It is therefore very expedient to elucidate on the microstructural effects of diabetes on the stomach as well as the intervention of herbal therapy to ameliorate the defects. The physical manifestation of the STZ induction on the fur of animals in the untreated diabetic group which included alopecia and wetness of fur may be due to polyuria. Polyuria is one of the conditions associated with diabetes (Abdelmoaty et al., 2010; Livingstone \& Davis, 2007; Manonmani et al., 2005; Maritim et al., 2003; Baynes \& Thorpe, 1996). Glucose in the urine causes osmotic diuresis, leading to increase in urine production (polyuria). Apart from polyuria, low immunity, thin skin, seborrhea and recurrent bacterial infections have been known to be responsible for hair loss in diabetes (Baynes \& Thorpe). Investigation has shown that diabetes is among other conditions that may also alter DNA transcription (Bremner, 2003) thus decreasing the size and output of sebaceous glands, making the cells that are sloughed off into the sebaceous glands less sticky, and therefore less able to form comedones. The absence of alopecia in animals treated with $X$. aethiopica may be due to improvement in the immune system as well as reduction in polyuria, conditions which if hitherto are present, would adversely affect the physical state of the animals. The average body weight of untreated diabetic animals was observed to decrease steadily when compared with the steady increment in the extract treated group. This observation may be related to free radical generated as a result of ill health caused by the diabetic state in the untreated diabetic animals. This is in corroboration with previous studies by Abdelmoaty et al. and Halliwell \& Gutteridge (1999). The observed increase in the percentage relative weight of the stomach in the untreated diabetic group is in line with the report of Bastaki et al. But on the contrary, the increase in percentage relative weight of the stomach of untreated diabetic animals may be due to an increased compensatory mechanism leading to the restoration of the depleted intestinal cell of Cajal in the gastric muscle layers which are always compromised in diabetic state. Qiu et al. (2010) reported a reduction of interstitial cells of Cajal in the gastric muscle layer in the diabetic mice. Investigation by Mei et al. (2006) revealed that interstitial cells of Cajal could regenerate and restore their normal distribution after being disrupted in adult guinea pigs.

The observation from this result showed that the microanatomy of the gastric mucosa of the control animals presented a well organized and normal outline as against the disorganization observed in the untreated diabetic animals. Apart from this, the parietal cells were scanty in the untreated diabetic rats as compared with the control and extract treated animals. This confirms that diabetes induces pathological changes in gastric tissue in line with previous study by Ofusori et al. (2012). Membranes of parietal cell has been reported to be disruptive and lack flexibility in a diabetic state thus compromising the molecular mechanisms that allow for the essential link between the membranes and F-actin, necessary to the gross architecture of the secretory membranes (Miller et al., 2002; Bastaki et al.). Furthermore, diabetes has been reported to cause series of gastric complications ranging from sensation, abnormalities in intestinal motility, secretion, and absorption (Wolosin \& Edelman; Ofusori et al.). Okokon et al. (2011) reported that peptic ulcer disease is always implicated in diabetes due to scavenging free radicals. Thus, the leaf extract of $X$. aethiopica maintained the integrity of the gastric mucosa to near normal in this study.

The integrity of ion channels in the parietal cells was assessed to underscore its functionality. This was demonstrated by targeting the $\mathrm{H}+\mathrm{K}+$-ATPase in the parietal cells using monoclonal antibodies specific for gastric proton pump. We observed a significant reduction in the percentage immunoreactivity of in $\mathrm{H}+/ \mathrm{K}+$-ATPase -positive parietal cells in untreated diabetic animals as evident by the scanty staining intensity within the gastric mucosa. This is a substantive proof of compromised gastric proton pump. This suggests a reduction in the $\mathrm{HCl}$ secretion by the parietal cells. Investigation documented in mice showed that diabetes result in the decline of the integrity of $\mathrm{H}+$ / $\mathrm{K}+-$ ATPase (Miller et al.). The $\mathrm{H}+/ \mathrm{K}+-\mathrm{ATPase}$ causes the exchange of a proton against a potassium ion through a membrane thus making the gastric fluid acidic. This study is in line with previous report on the reduction of $\mathrm{H}+/ \mathrm{K}+-$ ATPase in the parietal cells of diabetic rats using an antibody against the enzyme (Bastaki et al.). The diabetic animals treated with leaf extract of $X$. aethiopica shows a gradual recovery of gastric proton pump. The mechanism by which $X$. aethiopica brings about the recovery process of $\mathrm{H}+/ \mathrm{K}+-$ ATPase may be due to its high flavonoid content. Series of researches have shown that $X$. aethiopica contains antioxidant properties (Ameyaw \& Owusu-Ansah, 1998; Adefegha \& Oboh, 2012).

The ultrastructural assessment of untreated diabetic animals showed that there was a reduction in the mitochondrial density in the parietal cells as well as predominance of euchromatin over heterochromatin in the parietal cell nucleus. This result is not the first of its kind as Bastaki et al. and Maha et al. (2012) reported similar 
observation in diabetic rats. Even though this observation calls for more investigation, it may not be unconnected with oxidative stress caused by the increased reactive oxygen species production which normally leads to pathological changes. Report has shown that free-radical production is consistently elevated in diabetes (KedzioraKornatowska et al., 2003). Mitochondria are needed in large quantity by the parietal cells to provide the needed adenosine triphosphate (ATP) necessary for acid secretion. Thus, mitochondrial-stress mediated cell-death in diabetic animals in this study suggests a low gastric acid output in line with Bastaki et al. There is a distinctive relationship between the actively productive cell and the amount of euchromatin resident in nucleus. It is assumed that the increased euchromatin in the nuclei of parietal cells of untreated diabetic rats are compensatory activity geared at renewing/restoring cells damaged during the diabetic state. The treatment of diabetic animals with leaf extract of $X$. aethiopica demonstrates a gradual restoration/ increase in the mitochondrial density as well as uniformly dispersed chromatin when compared with untreated diabetic group.

It is concluded that diabetes causes gastric pathology thus resulting in morphological changes in the gastric histoarchitecture and parietal cells. The aqueous leaf extract of Xylopia aethiopica enhances the recovery/restoration process in streptozotocin induced diabetic rats which some synthetic anti-diabetic drugs failed to achieve and as such, may play a significant role in the management of complications associated with diabetes mellitus. This however justifies the ethno-medicinal use of the $X$. aethiopica in the management of diabetes mellitus.

\section{ACKNOWLEDGEMENTS}

We appreciate the funding support received from tertiary education trust fund (TETFund) for the execution of this research.

OFUSORI, D. A.; KOMOLAFE, O. A; ADEWOLE, O. S.; ARAYOMBO, B. E; MARGOLIS, D. \& NAICKER, T. Efectos ultraestructurales e inmunohistoquímicos de extracto acuoso de la hoja Xylopia aethiopica en el estómago de ratas diabéticas inducidas por estreptozotocina. Int. J. Morphol., 34(1):34-41, 2016.

RESUMEN: La enfermedad gastrointestinal en pacientes diabéticos se ha convertido en una fuente de preocupación en los últimos tiempos. El objetivo fue investigar los efectos ultraestructurales e inmunohistoquímicos de extracto acuoso de la hoja de Xylopia aethiopica en el estómago de ratas con diabetes inducida por estreptozotocina. Se utilizaron 30 ratas Wistar adul- tas, divididas en tres grupos $(n=10)$. El Grupo A, control (se le administró un volumen equivalente de tampón de citrato); el Grupo $\mathrm{B}$, animales diabéticos inducidos por una sola inyección intraperitoneal de estreptozotocina disuelta en tampón de citrato (65 mg/kg) y el Grupo C, animales diabéticos con $200 \mathrm{mg} / \mathrm{kg}$ peso corporal tratados con extracto acuoso de X. aethiopica durante 25 d. Luego, todos los animales fueron sacrificados, se les extirpó el estómago y fijó en formol al $10 \%$ y en fijador Karnovsky para anticuerpos monoclonales contra la bomba de protones gátrica $\mathrm{H}+$ / $\mathrm{K}+$-ATPasa; las muestras se observaron mediante microscopías óptica y electrónica. Los resultados mostraron una disminución gradual $(\mathrm{P}<0,05)$ en el nivel de glucosa en sangre del grupo tratado con el extracto, contra un incremento en el grupo diabético no tratado. Hubo una distorsión de la mucosa glandular y el epitelio en el grupo diabético no tratado vis-à-vis los grupos tratados con extracto y el de control. La tinción inmunohistoquímica del estómago del grupo diabético no tratado, mostró escasas células parietales inmunorreactivas en el grupo diabético no tratado comparado con el grupo control. Hubo un mejor patrón de tinción en la bomba de protones gátrica $\mathrm{H}+/ \mathrm{K}+-\mathrm{ATPasa}$ en el grupo tratado con el extracto de hoja acuosa de $X$. aethiopica, en comparación con el grupo diabético no tratado. Los estudios ultraestructurales del grupo diabético no tratado revelaron una reducción en la densidad de las mitocondrias en comparación con el grupo control. El tratamiento con extracto de hoja de $X$. aethiopica aumentó la densidad mitocondrial, así como la dispersión uniforme de la cromatina. Se concluye que la diabetes causa una enfermedad gástrica que genera cambios morfológicos en la histoarquitectura de las células parietales gástricas. El extracto de hoja acuosa de $X$. aethiopica mejora la recuperación/restauración de estos defectos en ratas diabéticas inducidas por estreptozotocina y, como tal, puede jugar un rol significativo en el tratamiento de las complicaciones asociadas con la diabetes mellitus.

PALABRAS CLAVE: Diabetes mellitus; Inmunohistoquímica; Ultraestructura; Estómago; Xylopia aethiopic.

\section{REFERENCES}

Abdelmoaty, M. A.; Ibrahim, M. A.; Ahmed, N. S. \& Abdelaziz, M. A. Confirmatory studies on the antioxidant and antidiabetic effect of quercetin in rats. Indian J. Clin. Biochem., 25(2):188-92, 2010.

Adefegha, S. A. \& Oboh, G. Effect of diets supplemented with Ethiopian pepper [Xylopia aethiopica (Dun.) A. Rich (Annonaceae)] and Ashanti pepper [Piper guineense Schumach. et Thonn (Piperaceae)] on some biochemical parameters in normal rats. Asian Pac. J. Trop. Biomed., 2(2 Suppl.):S558-66, 2012.

Akbarzadeh, A.; Norouzian, D.; Mehrabi, M. R.; Jamshidi, S. h.; Farhangi, A.; Verdi, A. A.; Mofidian, S. M. \& Rad, B. L. Induction of diabetes by Streptozotocin in rats. Indian J. Clin. Biochem., 22(2):60-4, 2007.

Ameyaw, Y. \& Owusu-Ansah, E. Morphohistological studies of two plant species used in ethnomedicine. Ethnobot. Leafl., 2005(1):Article 13, 2005. Available at: http://opensiuc.lib.siu.edu/ebl/vol2005/iss1/13 
OFUSORI, D. A.; KOMOLAFE, O. A; ADEWOLE, O. S.; ARAYOMBO, B. E; MARGOLIS, D. \& NAICKER, T. Ultrastructural and immunohistochemical effects of aqueous leave extract of Xylopia aethiopica on the stomach in streptozotocin-induced diabetic rats. Int. J. Morphol., 34(1):34-41, 2016.

Bailey, C. J. \& Day, C. Traditional plant medicines as treatments for diabetes. Diabetes Care, 12(8):553-64, 1989.

Baldé, N. M.; Youla, A.; Baldé, M. N.; Kaké, A.; Diallo, M. M.; Baldé, M. A. \& Maugendre, D. Herbal medicine and treatment of diabetes in Africa: an example from Guinea. Diabetes Metab., 32(2):171-5, 2006.

Bastaki, S. M.; Adeghate, E.; Chandranath, I. S.; Amir, N.; Tariq, S.; Hameed, R. S. \& Adem, A. Effects of streptozotocin-induced longterm diabetes on parietal cell function and morphology in rats. Mol. Cell. Biochem., 341(1-2):43-50, 2010.

Baynes, J. W. \& Thorpe, S. R. The role of oxidative stress in diabetic complications. Curr. Opin. Endocrinol. Diabetes Obes., 3(4):27784, 1996.

Bernard, C.; Thibault, C.; Berthault, M. F.; Magnan, C.; Saulnier, C.; Portha, B.; Pralong, W. F.; Pénicaud, L. \& Ktorza, A. Pancreatic beta-cell regeneration after 48 -h glucose infusion in mildly diabetic rats is not correlated with functional improvement. Diabetes, 47(7):1058-65, 1998.

Bremner, J. D. Does isotretinoin cause depression and suicide? Psychopharmacol. Bull., 37(1):64-78, 2003.

Deshmukh, T. A; Yadav, B. V; Badole, S. L. \& Bodhankar, S. L. Antihyperglycaemic activity of alcoholic extract of Aerva lanata (L.) A. L. Juss. Ex J. A. Schultes leaves in alloxan induced diabetic mice. J. Appl. Biomed., 6:81-7, 2008.

Halliwell, B. \& Gutteridge, J. M. C. Free Radicals in Biology and Medicine. $3^{\text {rd }}$ ed. New York, The Clarendon Press, Oxford University Press, 1999.

Kedziora-Kornatowska, K.; Szram, S.; Kornatowski, T.; SzadujkisSzadurski, L.; Kedziora, J. \& Bartosz, G. Effect of vitamin E and vitamin $\mathrm{C}$ supplementation on antioxidative state and renal glomerular basement membrane thickness in diabetic kidney. Nephron Exp. Nephrol., 95(4):e134-43, 2003.

Livingstone, C. \& Davis, J. Review: Targeting therapeutics against glutathione depletion in diabetes and its complications. $\mathrm{Br}$. J. Diabetes Vasc. Dis., 7(6):258-65, 2007.

Maha, M.; Abo, G. \& Hasan, N. M. Effect of glabridin on the structure of ileum and pancreas in diabetic rats: a histological, immunohistochemical and ultrastructural study. Nat. Sci., 10(3):7890, 2012.

Manonmani, G.; Bhavapriya, V.; Kalpana, S.; Govindasamy, S. \& Apparanantham, T. Antioxidant activity of Cassia fistula (Linn.) flowers in alloxan induced diabetic rats. J. Ethnopharmacol., 97(1):39-42, 2005.

Maritim, A. C.; Sanders, R. A. \& Watkins, J. B. $3^{\text {rd }}$. Diabetes, oxidative stress, and antioxidants: a review. J. Biochem. Mol. Toxicol., 17(1):24$38,2003$.

Mei, F.; Yu, B.; Ma, H.; Zhang, H. J. \& Zhou, D. S. Interstitial cells of Cajal could regenerate and restore their normal distribution after disrupted by intestinal transection and anastomosis in the adult guinea pigs. Virchows Arch., 449(3):348-57, 2006.

Miller, M. L.; Judd, L. M.; Van Driel, I. R.; Andringa, A.; Flagella, M.; Bell, S. M.; Schultheis, P. J.; Spicer, Z. \& Shull, G. E. The unique ultrastructure of secretory membranes in gastric parietal cells depends upon the presence of H+, K+-ATPase. Cell Tissue Res., 309(3):369$80,2002$.

Movassat, J.; Saulnier, C. \& Portha, B. Insulin administration enhances growth of the beta-cell mass in streptozotocin-treated newborn rats. Diabetes, 46(9):1445-52, 1997.

Ofusori, D. A.; Komolafe, O. A. \& Adewole, O. S. Ethanolic leaf extract of croton zambesicus (MÜll. Arg.) improves gastric emptying capacity and gastric mucosa integrity in streptozotocin-induced diabetic rats. Int. J. Diabetes Res., 1(4):58-67, 2012.

Ogbonnia, S.; Adekunle, A. A.; Bosa, M. K. \& Enwuru, V. N. Evaluation of acute and subacute toxicity of Alstonia congensis Engler (Apocynaceae) bark and Xylopia aethiopica (Dunal) A. Rich (Annonaceae) fruits mixtures used in the treatment of diabetes. Afr. J. Biotechnol., 7(6):701-5, 2008.

Okokon, J. E.; Umoh, U. F.; Udobang, J. A. \& Etim, E. I. Antiulcerogenic activity of ethanolic leaf extract of Croton Zambesicus Muell. Arg. Afr. J. Biomed. Res., 14(1):43-7, 2011.

Piyachaturawat, P.; Poprasit, J. \& Glinsukon, T. Gastric mucosal secretions and lesions by different doses of streptozotocin in rats. Toxicol. Lett. 55(1):21-9, 1991

Qiu, Z. X.; Mei, B.; Wu, Y. S.; Huang, X.; Wang, Z. Y.; Han, Y. F.; Lu, H. L.; Kim, Y. C. \& Xu, W. X. Atrial natriuretic peptide signal pathway upregulated in stomach of streptozotocin-induced diabetic mice. World J. Gastroenterol., 16(1):48-55, 2010.

Reynolds, E. S. The use of lead citrate at high $\mathrm{pH}$ as an electron-opaque stain in electron microscopy. J. Cell. Biol., 17:208-12, 1963.

Wolosin, J. D. \& Edelman, S. V. Diabetes and the gastrointestinal tract. Clin. Diabetes, 18(4):148-51, 2000.

Yamano, M.; Takeshi, K.; Nagakura, Y. \& Miyata, K. Effects of gastroprokinetic agents on gastroparesis in streptozotocin-induced diabetic rats. Naunyn Schmiedebergs Arch. Pharmacol., 356(1):14550, 1997.

\section{Correspondence to:}

D. A. Ofusori

Department of Anatomy and Cell Biology

Faculty of Basic Medical Sciences

Obafemi Awolowo University

le-lfe, Osun State

NIGERIA

\section{Email: davidofus234@yahoo.com}

Received: 04-05-2015

Accepted: 15-10-2015 